\title{
Keragaman Genetik dan Ketahanan terhadap Penyakit Layu Fusarium (Fusarium oxysporum f.sp cepae) Bawang Merah (Allium cepa $\mathrm{L}$. var. aggregatum) Indonesia
}

\section{Genetic Diversity and Fusarium Wilt Disease Resistance (Fusarium oxysporum f.sp cepae) of Indonesian Shallots (Allium cepa L. var aggregatum)}

\author{
Ita Aprilia ${ }^{1}$, Awang Maharijaya ${ }^{1,2 *}$, Sobir ${ }^{1,2}$, dan Suryo Wiyono ${ }^{1,3}$
}

Diterima 12 Maret 2018/Disetujui 07 Januari 2020

\begin{abstract}
Genetic diversity is important in breeding program. Fusarium wilt resistant is one of the character that desired in the superior variety in shallot. This study was aimed to obtaining the genetic diversity based on morpholigical marker, ISSR moleculer marker, and resistant to wilt fusarium disease character of 19 Indonesian shallot genotypes. The experiment used randomized complete block design, with three replications, and shallot genotypes as a treatment. Fusarium oxysporum f.sp cepae was isolated from shallot plant that cultivated in Brebes, Central Java was used in this study that artificially innoculated on the shallot genotypes. The results showed that there were genetic diversity based on morphological character, ISSR moleculer marker, and fusarium wilt resistant. Batu Ijo and Rubaru were more resistance than the other genotypes based on incubation periode, disease incident, and infection rate.
\end{abstract}

Keywords: breeding, fungal disease, resistant variety, twisting

\begin{abstract}
ABSTRAK
Keragaman genetik merupakan hal yang penting dalam kegiatan pemuliaan tanaman. Ketahanan terhadap penyakit layu fusarium merupakan salah satu karakter yang diharapkan dalam pengembangan varietas bawang merah. Penelitian bertujuan untuk memperoleh informasi keragaman genetik berdasarkan marka morfologi, marka molekuler ISSR, dan ketahanan terhadap penyakit layu fusarium dari 19 genotipe bawang merah Indonesia. Penelitian menggunakan rancangan kelompok lengkap teracak (RKLT) dengan tiga ulangan dan satu faktor yaitu genotipe bawang merah. Isolat Fusarium oxysporum f.sp cepae yang digunakan sebagai bahan uji didapatkan dari tanaman yang terserang penyakit layu fusarium di Brebes, Jawa Tengah. Hasil penelitian menunjukkan terdapat keragaman genetik berdasarkan marka morfologi, molekuler ISSR, dan ketahanan terhadap penyakit layu fusarium pada genotipe bawang merah yang diamati. Genotipe Batu Ijo dan Rubaru merupakan genotipe dengan ketahanan terhadap penyakit layu fusarium terbaik dibandingkan genotipe lainnya berdasarkan parameter periode inkubasi penyakit, kejadian penyakit, dan laju infeksi penyakit.
\end{abstract}

Kata kunci: moler, pemuliaan, penyakit cendawan, varietas tahan

\section{PENDAHULUAN}

Bawang merah menjadi komoditas penting di Indonesia karena fungsi utamanya sebagai salah satu komponen bumbu utama hampir seluruh masakan. Bawang merah selain kaya akan kandungan gizi, juga berpotensi sebagai obat karena mengandung senyawa alliin yang bermanfaat sebagai antiseptik (BRC, 2015). Rerata konsumsi bawang merah per kapita per minggu pada tahun 2013 hingga 2016 terus menunjukkan adanya peningkatan

\footnotetext{
${ }^{1}$ Pusat Kajian Hortikultura Tropika (PKHT) IPB, Kampus IPB Baranangsiang

Jl. Raya Padjajaran, Kampus IPB Baranangsiang, Bogor 16141, Indonesia

${ }^{2}$ Departemen Agronomi dan Hortikultura, Fakultas Pertanian, Institut Pertanian Bogor

Jl. Meranti, Kampus IPB Darmaga, Bogor 16680, Indonesia

${ }^{3}$ Departemen Proteksi Tanaman, Fakultas Pertanian, Institut Pertanian Bogor

Jl. Meranti, Kampus IPB Darmaga, Bogor 16680, Indonesia

E-mail : awang.maharijaya@gmail.com (*penulis korespondensi)
} 
(BPS, 2017). Estimasi pertambahan jumlah penduduk, berdasarkan data tersebut, maka akan berkorelasi positif terhadap pertambahan jumlah konsumsi bawang merah. Mengingat peran penting dan potensi komoditas bawang merah tersebut, maka peningkatan produksi harus terus dilakukan.

Salah satu kendala dalam peningkatan produksi bawang merah adalah hadirnya penyakit tanaman. Layu fusarium merupakan salah satu penyakit penting yang menyerang tanaman bawang merah di lapangan maupun dalam penyimpanan yang disebabkan oleh cendawan Fusarium oxysporum f.sp cepae. Cendawan tersebut memiliki kemampuan membentuk klamidospora sehingga memungkinkan untuk bertahan di dalam tanah dalam waktu yang yang cukup panjang meskipun tanpa tanaman inang (Udiarto et al., 2005). Kehilangan hasil akibat serangan penyakit layu fusarium dalam penelitian Prakoso et al. (2016) dapat terjadi sangat tinggi yaitu melebihi $50 \%$.

Peningkatan produksi bawang merah salah satunya dapat dicapai melalui penggunaan varietas unggul yang memiliki karakter ketahanan terhadap penyakit layu fusarium tersebut. Varietas unggul dapat dirakit melalui serangkaian proses pemuliaan tanaman meliputi koleksi, karakterisasi (identifikasi keragaman genetik), seleksi, pengujian, dan pelepasan varietas (Syukur et al., 2015). Penelitian ini berada pada tahapan koleksi dan karakterisasi. Koleksi dilakukan dengan memanfaatkan varietas yang sudah ada/banyak digunakan oleh petani. Keragaman genetik diidentifakasi melalui analisis keragaman marka morfologi dan keragaman sekuens DNA menggunakan marka molekuler Inter Simple Sequence Repeat (ISSR), serta identifikasi karakter ketahanan terhadap penyakit layu fusarium. Tujuan penelitian ini adalah memperoleh informasi keragaman genetik berdasarkan marka morfologi, molekuler ISSR, dan karakter ketahanan terhadap penyakit layu fusarium pada plasma nutfah bawang merah koleksi.

\section{BAHAN DAN METODE}

Penelitian ini dilaksanakan pada Bulan Januari 2017 sampai Januari 2018. Materi genetik yang berhasil dikumpulkan dan dijadikan bahan analisis sebanyak 19 genotipe di antaranya Batu Ijo, Bauji, Bima Brebes, Biru Lancor, Katumi, Kramat 1, Lembah Palu, Maja Cipanas, Manjung, Mentes, Palasa, Pancasona, Pikatan, Rubaru, Super Philip, Tajuk, Trisula, Bentanis, dan Bima Curut.

\section{Percobaan 1. Analisis Keragaman Genetik Bawang Merah Indonesia berdasarkan Marka Morfologi dan Molekuler ISSR}

\subsection{Keragaman Genetik Berdasarkan Marka Morfologi}

Genotipe bawang merah yang berumlah 19 ditanam sesuai dengan prosedur penanaman standar bawang merah di lahan budidaya bawang merah di Brebes, Jawa Tengah. Pengamatan marka morfologi dilakukan terhadap karakter kualitatif yang mengacu pada panduan yang terbitkan oleh PPVT (2013) dan Calibration Book: Onion and Shallot (Naktuinbow, 2010). Karakter morfologi yang diamati meliputi karakter-karakter pada tajuk (daun) di antaranya jumlah daun pada batang semu, perilaku tajuk, intensitas warna hijau daun, kelengkungan tajuk, panjang dan diameter daun, dan karakter pada umbi di antaranya bentuk umbi secara membujur, ukuran umbi, tinggi umbi, diameter umbi, tingkat membelah umbi menjadi bagian-bagian (kulit umbi kering), rasio tinggi/diameter, posisi diameter terluas, bentuk ujung batang, bentuk ujung akar, warna dasar kulit umbi kering, intensitas warna dasar kulit umbi kering, serta lebar leher umbi. Pengamatan karakter pada tajuk dilakukan pada saat pertumbuhan vegetatif tanaman maksimal (sekitar umur 5 MST), sedangkan pengamatan pada umbi dilakukan pada saat panen dan umbi telah dikeringkan selama sekitar 2 minggu.

Data karakterisasi kemudian diterjemahkan dinotasikan dalam angka sesuai panduan PPVT (2013) kemudian dilakukan analisis kekerabatan menggunakan perangkat pengolah data yang diakses pada http:// www.pbstat.com dengan metode Dissimilarity Gower dan metode Clustering Average Linkage.

\subsection{Keragaman Genetik Berdasarkan Marka Molekuler ISSR}

Analisis keragaman genetik diawali dengan isolasi DNA dari organ daun menggunakan metode CTAB. DNA bawang 
merah yang berhasil diisolasi kemudian dicek kualitasnya sebelum digunakan pada tahap selanjutnya. Cek kualitas DNA menggunakan dua metode yaitu pertama, melalui elektroforesis kemudian visualisasi menggunakan sinar UV dan metode kedua, menggunakan alat Nanodrop spektrofotometer. Amplifikasi DNA dilakukan menggunakan mesin PCR bermerk Applied Biosystem 2720 thermal cycler dengan 9 primer Inter Simple Sequence Repeat (ISSR) koleksi Pusat Kajian Hortikultura Tropika (PKHT) IPB (Tabel 1).

Tahapan proses PCR meliputi pradenaturasi, denaturasi, annealing, elongation, final extention, dan penurunan (Tabel 2). Hasil analisis genetik berdasarkan marka molekuler berupa data muncul dan tidak muncul pita, kemudian diterjemahkan menjadi data biner yaitu 0 untuk genotipe yang tidak muncul pita pada lokus tertentu dan 1 untuk genotipe yang muncul pita. Data tersebut kemudian dilakukan analisis kekerabatan menggunakan perangkat pengolah data yang diakses pada http:// www.pbstat.com/ metode Dissimilarity Gower dan metode clustering Avarage Linkage.

\section{Percobaan 2. Analisis Karakter Ketahanan terhadap Penyakit Layu Fusarium}

Cendawam F. oxysporum f.sp cepae diisolasi dari tanaman yang terinfeksi penyakit layu fusarium yang diperoleh dari lahan budidaya bawang merah Brebes, Jawa Tengah, kemudian diperbanyak dalam media PDA. Umbi bahan tanam diberi perlakukan perendaman air panas mengikuti metode Kaeni et al. (2014) dengan modifikasi suhu dan lama perendaman yaitu $53{ }^{\circ} \mathrm{C}$ selama 30 menit yang bertujuan untuk mengeliminasi cendawan Fusarium spp. yang terbawa umbi. Inokulasi menggunakan metode perendaman umbi bawang merah dalam suspensi inokulum Fusarium spp. dengan kerapatan $10^{5}$ selama 12 jam. Umbi bawang merah kemudian ditanam dalam polibag berukuran $30 \mathrm{~cm} \times 30 \mathrm{~cm}$ dengan media tanam berupa campuran tanah dan pupuk kompos dengan perbandingan 1:1 yang telah disterilisasi. Percobaan menggunakan rancangan kelompok lengkap teracak (RKLT) satu faktor yaitu genotipe dengan tiga ulangan. Setiap satu satuan percobaan terdapat 15 tanaman sebagai tanaman contoh.

Pengamatan dilakukan terhadap periode inkubasi penyakit, kejadian penyakit, dan laju infeksi penyakit. Kejadian penyakit dihitung menggunakan rumus $\mathrm{IP}=(\mathrm{X} / \mathrm{N}) \times 100 \%$, dengan IP $=$ indek penyakit, $X=$ jumlah tanaman sakit, $\mathrm{N}=$ jumlah seluruh tanaman hidup; sedangkan laju infeksi dihitung menggunakan rumus $r=(1 / \mathrm{t} 2-\mathrm{t} 1) \times(\operatorname{logit} \times 2-$ logitx1) dengan $r=$ laju infeksi, $t 1=$ waktu pengamatan saat pertama kali muncul gejala, $\mathrm{t} 2$ = waktu pengamatan saat muncul gejala kedua, $\mathrm{x} 1=$ kejadian penyakit pada saat $\mathrm{t} 1$ dan $\mathrm{x} 2=$ kejadian penyakit pada saat $\mathrm{t} 2$.

Tabel 1. Nama dan susunan basa primer ISSR yang digunakan dalam pengujian

\begin{tabular}{llcc}
\hline No & Nama & Susunan Basa & Suhu Annealing $\left({ }^{\circ} \mathrm{C}\right)$ \\
\hline 1 & PKBT2 & (AC)8TT & 53 \\
2 & PKBT4 & (AG)8AA & 53 \\
3 & PKBT7 & (GA)9A & 53 \\
4 & PKBT11 & (GT)9C & 55 \\
5 & ISSRRED5 & (AC)8SG & 47 \\
6 & ISSRRED7 & (GTC)6 & 51 \\
7 & ISSRRED9 & (CTC)5GC & 51 \\
8 & ISSRRED17 & (GAC)5 & 48 \\
9 & ISSRRED25 & (CCA)6 & 51 \\
\hline
\end{tabular}

Tabel 2. Tahapan, suhu, dan waktu dalam proses Plymerase Chain Reaction (PCR)

\begin{tabular}{lcccc}
\hline Tahapan & Siklus & Proses & Suhu $\left({ }^{\circ} \mathrm{C}\right)$ & Waktu \\
\hline I & 1 siklus & Pra-denaturasi & 94 & 4 menit \\
II & 35 siklus & Denaturasi & 94 & 30 detik \\
& & Annealing & $47-54$ & 1 menit \\
& & Elongation & 72 & 1 menit \\
III & 1 siklus & Final extention & 72 & 5 menit \\
IV & & Penyimpanan & 4 & Tak terhingga \\
\hline
\end{tabular}


Data yang diperoleh dianalisis dengan menggunakan uji-F. Apabila hasil yang diperoleh berpengaruh nyata maka dilakukan uji lanjut dengan metode Duncan Multiple Range Test (DMRT). Data hasil pengamatan tersebut juga digunakan dalam analisis kekerabatan berdasarkan nilai komponen ketahanan untuk menentukan kategori ketahanan genotipe terhadap penyakit layu fusarium menggunakan pengolah data yang diakses melalui http://www.pbstat.com/ metode Dissimilarity Gower dan metode clustering Avarage Linkage.

\section{HASIL DAN PEMBAHASAN}

\section{Keragaman Genetik Berdasarkan Marka Morfologi}

Bawang merah merupakan komoditas hortikultura dengan sistem perbanyakan dominan secara vegetatif. Genotipe bawang merah yang digunakan sebagai materi genetik dalam penelitian ini juga sebagian besar diperoleh melalui perkembangbiakan vegetatif yaitu melalui seleksi genotipe lokal, hanya genotipe Katumi, Kramat 1, Mentes, Pancasona, Pikatan, dan Trisula yang diperoleh melalui persilangan (Ditbenih Hortikultura, 2018). Perbanyakan tanaman secara vegetatif tidak/sedikit menghasilkan keragaman karena tidak adanya proses segregasi maupun percampuran materi genetik. Akan tetapi, berdasarkan marka morfologi, pada 19 genotipe bawang merah yang diamati menunjukkan adanya keragaman genetik. Keragaman tersebut ditunjukkan oleh koefisien ketidakmiripan pada dendrogram yaitu sekitar $0.55(55 \%)$ dan terpisahnya genotipe kedalam empat kelompok pada koefisien ketidakmiripan 0.35 (Gambar 1).

Pengelompokkan juga menggambarkan kekerabatan antar genotipe. Genotipe-genotipe yang berada dalam satu kelompok memiliki kekerabatan yang lebih dekat dibandingkan genotipe yang berbeda kelompok. Wahdah et al. (2012) melakukan analisis kekerabatan padi lokal pasang surut menyatakan aksesi padi yang terdapat pada gerombol (kelompok) yang sama memiliki kekerabatan yang dekat. Akan tetapi, pengelompokan berdasarkan marka morfologi seringkali belum menggambarkan kekerabatan genotipe secara akurat, hal tersebut karena dipengaruhi oleh faktor lingkungan dan keterbatasan karakter yang diamati. Kelemahan marka morfologi tersebut dapat diatasi dengan menggunakan marka molekuler. Marka molekuler mampu menggambarkan kekerabatan antar genotipe secara akurat karena berdasarkan sekuens DNA yang stabil.

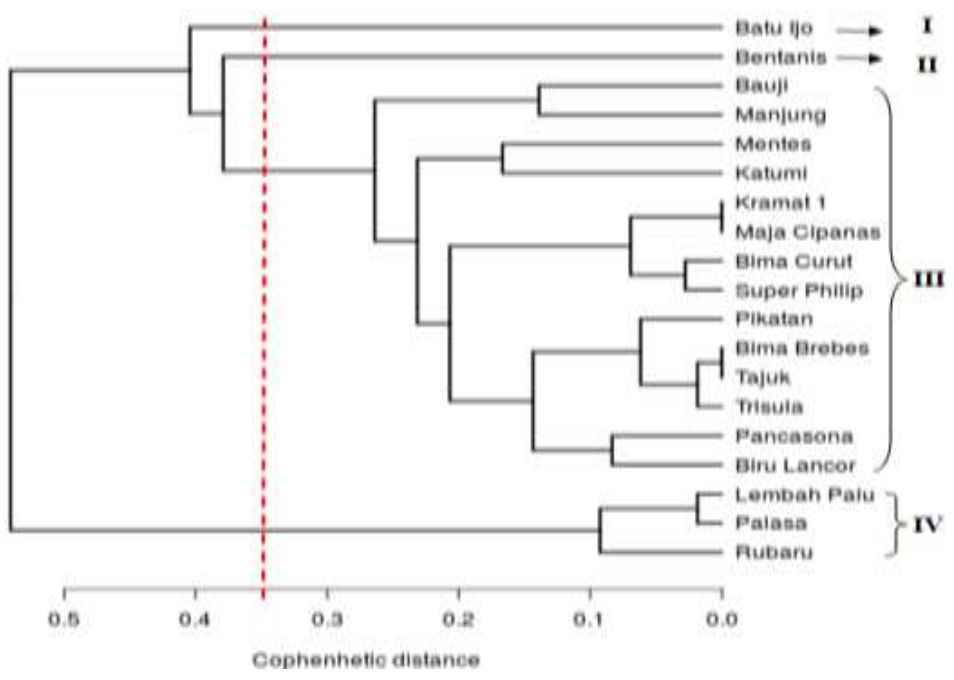

Gambar 1. Dendrogram berdasarkan karakter morfologi 


\section{Keragaman Genetik Berdasarkan Marka Molekuler}

Primer ISSR yang digunakan berhasil mengamplifikasi 74 pita diantaranya 69 pita polimorfik atau sebesar $93.24 \%$ dan 5 pita monomorfik atau sebesar $6.76 \%$. Pita polimorfik tersebut menggambarkan adanya keragaman genetik antar genotipe berdasarkan perbedaan susunan basa-basa DNA. Keragaman genetik berdasarkan marka molekuler ISSR pada bawang merah yang diamati juga terlihat dari koefisien ketidakmiripan sebesar 0.38 (38\%) pada dendrogram dan terpisahnya genotipe ke dalam 5 kelompok pada koefisien kemiripan $0.32(32 \%)$ (Gambar 2). Keragaman genetik pada tanaman yang dikembangbiakkan secara vegetatif dapat terjadi salah satunya karena mutasi alami yang tejadi dalam jangka waktu yang panjang, hal itu sekaligus menunjukkan tanaman tersebut telah lama dibudidayakan oleh masyarakat. Keragaman karena mutasi alami pernah ditunjukkan pada penelitian manggis yang sudah berumur 70 tahun yaitu terdapat perbedaan susunan DNA antara cabang tua dengan cabang muda, perbedaan tersebut diduga karena mutasi alami akibat faktor lingkungan (Sobir dan Syukur, 2015).

Primer ISSR merupakan primer yang yang dikembangkan dari sekuens DNA simple sequence repeat (SSR) atau situs dengan pola basa DNA berulang. Sekuens SSR merupakan sekuens DNA yang tersedia sangat melimpah dalam genom eukariota (Zietkiewicz et al., 1994). Sekuens berulang juga bermanfaat dalam memberikan gambaran kekerabatan antar genotipe (Sobir dan Syukur, 2015). Oleh sebab itu, marka molekuler ISSR banyak digunakan dalam analisis keragaman genetik pada spesies eukariota.

Husain et al. (2016) berhasil mengevaluasi keragaman genetik mutan harapan generasi MV1 jeruk kepok SoE menggunakan marka molekuler ISSR. Agisimanto et al. (2007) menyatakan dendogram yang dibentuk dari marka molekuler ISSR mampu menunjukkan keragaman dan jarak genetik lebih tinggi pada jeruk siam dibandingkan marka molekuler RAPD. Analisis keragaman genetik pada spesies bawang merah menggunakan marka molekuler ISSR juga telah banyak dilakukan seperti pada penelitian Sari et al. (2017). Samiei et al. (2015), dan Mukherjee et al. (2013).

Bawang merah meskipun dominan diperbanyak secara vegetatif, namun juga bisa diperbanyak melalui biji, sehingga dalam pengembangan varietas dapat ditempuh melalui persilangan buatan. Tanaman yang berkembangbiak secara vegetatif memiliki tipe penyerbukan silang dan heterozigositas tinggi yang dapat menyebabkan inbreeding depressionpada keturunan selfing-nya (Syukur et al., 2015), sehingga informasi kekerabatan antar genotipe yang ditampilkan dalam dendrogram (Gambar 2) bermanfaat dalam menetukan kombinasi persilangan.

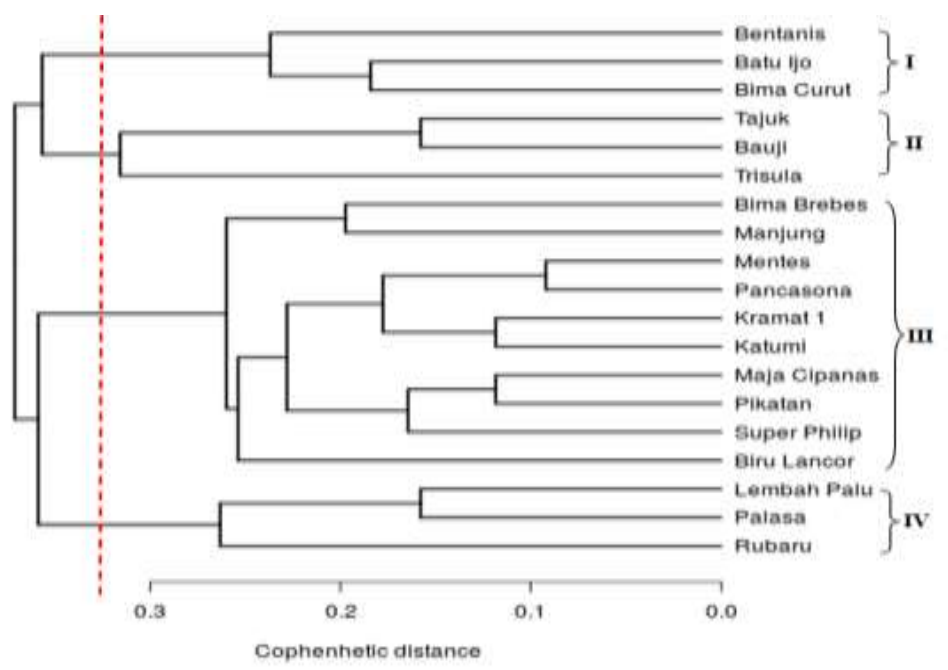

Gambar 2. Dendrogram analisis kekerabatan berdasarkan marka molekuler (DNA) ISSR pada 19 genotipe bawang merah Indonesia. 


\section{Karakter Ketahanan terhadap Penyakit Layu Fusarium}

Genotipe bawang merah yang diamati menunjukkan keragaman pada rerata nilai periode inkubasi penyakit, kejadian penyakit, laju infeksi penyakit, dan kategori ketahanan (Tabel 3). Periode inkubasi penyakit layu fusarium terjadi mulai dari 5 hari setelah tanam (HST) hingga 27 HST. Hasil penelitian Prakoso et al. (2016) menunjukkan, periode inkubasi penyakit yang berbeda yaitu berkisar antara 14 hingga 20 hari setelah tanam. Perbedaan periode inkubasi dapat disebabkan oleh beberapa faktor diantaranya ketahanan genotipe bawang merah, virulensi penyakit, dan kondisi lingkungan. Periode inkubasi penyakit layu fusarium dengan inokulasi buatan umumnya terjadi lebih awal dari pada infestasi alami di lapang. Hasil Penilitian Wiyatiningsih et al. (2009), menunjukkan periode inkubasi penyakit fusarium yang terjadi secara alami di lahan budidaya berkisar antara 14 hingga 50 hari setelah tanam, sedangkan hasil pengatamatan Supriyadi et al. (2013) menunjukkan budidaya bawang merah secara vertikultur mulai menunjukkan adanya serangan layu fusarium pada saat tanaman berumur 20 HST.

Kejadian penyakit layu fusarium terus mengalami peningkatan seiring dengan pertambahan umur tanaman. Kejadian penyakit pada saat tanaman berumur 5 MST berkisar antara $11.43 \%$ hingga $100 \%$. Periode inkubasi dan kejadian penyakit selanjutnya menentukan laju infeksi penyakit layu fusarium pada materi genetik yang digunakan. Laju infeksi penyakit terjadi mulai dari kecepatan 0.000 unit hari ${ }^{-1}$ hingga 0.045 unit hari ${ }^{-1}$.

Tabel 3. Rerata periode inkubasi penyakit, kejadian penyakit, dan laju infeksi penyakit

\begin{tabular}{lccc}
\hline Genotipe & $\begin{array}{c}\text { Periode Inkubasi Penyakit } \\
(\text { HST })\end{array}$ & $\begin{array}{c}\text { Kejadian Penyakit } \\
(\%)\end{array}$ & $\begin{array}{c}\text { Laju Infeksi } \\
\text { Penyakit } \\
\text { (unit/hari) }\end{array}$ \\
\hline Bima Brebes & $6.7 \mathrm{e}$ & $100.00 \mathrm{a}$ & $0.040 \mathrm{ab}$ \\
Bima Curut & $8.0 \mathrm{de}$ & $88.56 \mathrm{ab}$ & $0.017 \mathrm{~cd}$ \\
Bauji & $5.3 \mathrm{e}$ & $82.33 \mathrm{abc}$ & $0.029 \mathrm{abc}$ \\
Manjung & $6.3 \mathrm{e}$ & $72.70 \mathrm{abcd}$ & $0.024 \mathrm{abc}$ \\
Bentanis & $9.0 \mathrm{cde}$ & $71.96 \mathrm{abcd}$ & $0.032 \mathrm{abc}$ \\
Maja cipanas & $12.7 \mathrm{bcde}$ & $71.78 \mathrm{abc}$ & $0.031 \mathrm{abc}$ \\
Super philip & $10.3 \mathrm{bcde}$ & $70.00 \mathrm{abcd}$ & $0.031 \mathrm{abc}$ \\
Pancasona & $7.7 \mathrm{de}$ & $66.10 \mathrm{abcd}$ & $0.045 \mathrm{a}$ \\
Kramat 1 & $9.0 \mathrm{cde}$ & $63.33 \mathrm{abcd}$ & $0.033 \mathrm{abc}$ \\
Mentes & $7.7 \mathrm{de}$ & $55.04 \mathrm{bcde}$ & $0.030 \mathrm{abc}$ \\
Palasa & $9.0 \mathrm{cde}$ & $52.75 \mathrm{bcde}$ & $0.021 \mathrm{bc}$ \\
Biru Lancor & $13.0 \mathrm{bcde}$ & $46.93 \mathrm{cdef}$ & $0.019 \mathrm{~cd}$ \\
Tajuk & $17.0 \mathrm{bc}$ & $45.93 \mathrm{cdef}$ & $0.028 \mathrm{abc}$ \\
Pikatan & $10.0 \mathrm{cde}$ & $44.25 \mathrm{cdef}$ & $0.030 \mathrm{abc}$ \\
Katumi & $15.0 \mathrm{bcd}$ & $40.81 \mathrm{cdef}$ & $0.025 \mathrm{abc}$ \\
Trisula & $9.7 \mathrm{cde}$ & $34.43 \mathrm{def}$ & $0.021 \mathrm{bc}$ \\
Lembah palu & $12.3 \mathrm{bcde}$ & $25.84 \mathrm{efg}$ & $0.013 \mathrm{~cd}$ \\
Rubaru & $20.0 \mathrm{ab}$ & $18.04 \mathrm{fg}$ & $0.013 \mathrm{~cd}$ \\
Batu Ijo & $27.3 \mathrm{a}$ & $11.43 \mathrm{~g}$ & $0.000 \mathrm{~d}$ \\
\hline Keterangan: Angka yang diikuti huruf yang sama menunjukkan nilai yang tidak berbeda nyata berdasarkan uji DMRT & &
\end{tabular}

Tabel 4. Korelasi karakter periode inkubasi, intensitas penyakit, dan laju infeksi pada 19 genotipe bawang merah Indonesia

\begin{tabular}{lccc}
\hline & Periode Inkubasi & Intensitas Penyakit & Laju Infeksi \\
\hline Periode inkubasi & 1 & & \\
Intensitas penyakit & $-0.7683^{* *}$ & 1 & \\
Laju infeksi & $-0.6813^{* *}$ & $0.6880^{* *}$ & 1 \\
\hline Keterangan: *nyata pada nilai 5\%**sangat nyata pada nilai $1 \%$. & &
\end{tabular}


Periode inkubasi penyakit, kejadian penyakit, dan laju infeksi penyakit memiliki hubungan yang erat dalam menentukan karakter ketahanan tanaman terhadap penyakit layu fusarium, hal tersebut ditunjukkan oleh hasil analisis korelasi (Tabel 4). Analisis korelasi menunjukkan periode inkubasi berkorelasi negatif sangat nyata terhadap intensitas penyakit dan laju infeksi. Hal tersebut menunjukkan bahwa semakin lama periode inkubasi penyakit layu fusarium pada genotipe bawang merah yang diamati cenderung memiliki nilai intensitas penyakit rendah dan laju infeksi yang lambat. Analisis korelasi juga menunjukkan intensitas penyakit berkorelasi positif sangat nyata terhadap laju infeksi yang berarti bahwa semakin tinggi intensitas penyakit cenderung semakin tinggi juga laju infeksi dari penyakit layu fusarium.

Keterkaitan antar parameter pengamatan berdasarkan analisis korelasi, menunjukkan bahwa satu parameter sudah dapat menjelaskan karakter ketahanan genotipe. Akan tetapi, hal ini akan menjadi lebih akurat dengan menggabungkan semua parameter dan dianalisis dalam analisis kekerabatan. Hasil analisis kekerabatan dalam bentuk dendrogram menggunakan data parameter pengamatan ketahanan tersebut, mengelompokkan 19 genotipe bawang merah yang diamati berdasarkan kemiripan nilai parameter pengamatan tersebut. Hasil dendrogram memisahkan ke 19 genotipe tersebut ke dalam tiga kelompok (Gambar 3).
Kelompok I merupakan kelompok dengan genotipe yang cenderung memiliki persentase kejadian penyakit paling tinggi, laju infeksi penyakit paling cepat, dan periode inkubasi penyakit paling awal sehingga dapat dikategorikan rentan. Kelompok II merupakan kelompok dengan genotipe yang cenderung memiliki persentase kejadian penyakit sedang (lebih rendah dari kelompok I dan lebih tinggi dari kelompok III), laju infeksi penyakit cenderung lebih lambat dari kelompok I dan lebih cepat dari kelompok III, dan periode inkubasi penyakit lebih lambat dari kelompok I dan lebih cepat dari kelompok III sehingga dapat dikategorikan agak tahan. Kelompok III adalah kelompok dengan persentase kejadian penyakit paling rendah, periode inkubasi penyakit paling lama, dan laju infeksi penyakit paling lambat sehingga dapat dikategorikan tahan. Berdasarkan hasil tersebut, menunjukkan bahwa genotipe Batu Ijo dan Rubaru berpotensi sumber genetik sifat ketahanan terhadap penyakit layu fusarium dalam pengembangan komoditas bawang merah. Genotipe Batu Ijo dan Rubaru dalam dendogram berdasarkan marka morfologi berada dalam kelompok yang berbeda dan memiliki koefisien ketidakmiripan yang cukup tinggi yaitu 0.69 , hal tersebut menunjukkan karakter ketahanan terhadap penyakit layu fusarium tidak terpaut dengan karakter morfologi tertentu.

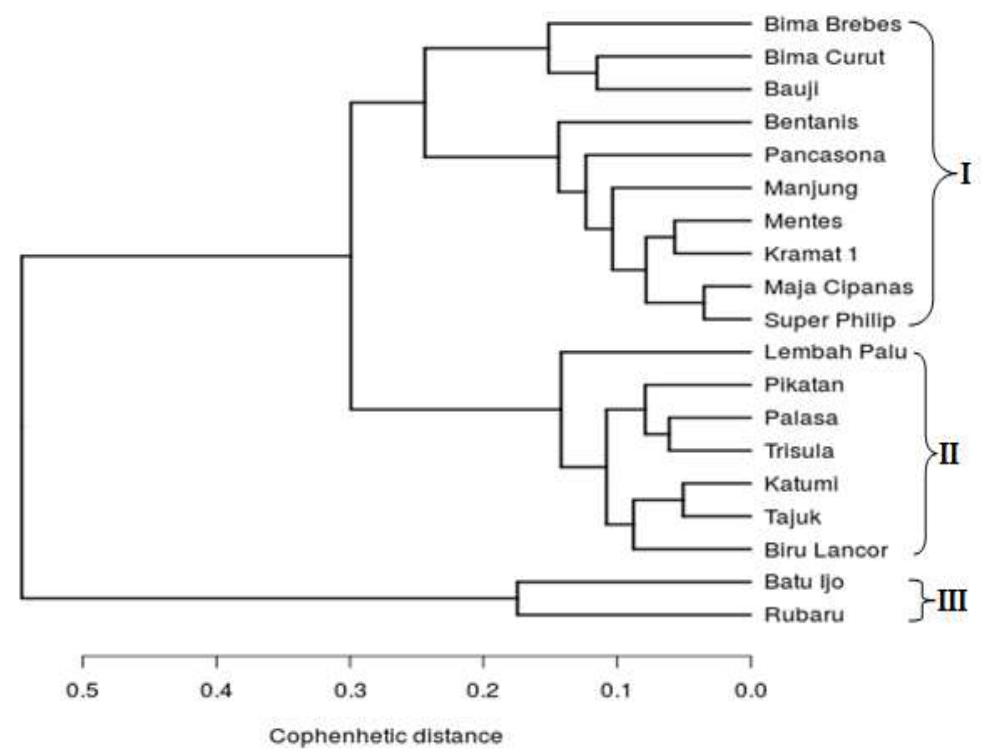

Gambar 3. Dendrogram berdasarkan parameter ketahanan 


\section{KESIMPULAN}

Genotipe-genotipe bawang merah yang diamati memiliki keragaman genetik berdasarkan karakter morfologi, marka molekuler, dan sifat ketahanan terhadap penyakit layu fusarium. Koefisien kemiripan 19 genotipe bawang merah yang diamati sebesar 0.19 berdasarkan karakter morfologi dan 0.58 berdasarkan marka molekuler. Karakter ketahanan terhadap penyakit layu fusarium dari 19 genotipe yang diamati terbagi dalam tiga kategori level ketahanan yaitu tahan, agak tahan, dan rentan. Genotipe Batu Ijo dan Rubaru termasuk dalam kategori tahan, Genotipe Biru Lancor, Katumi, Lembah Palu, Pikatan, Tajuk, dan Trisula termasuk dalam kategori agak tahan. Genotipe Bentanis, Kramat 1, Maja Cipanas, Manjung, Mentes, Palasa, Pancasona, Super Philip, Bauji, Bima Brebes, dan Bima Curut termasuk dalam kategori rentan.

\section{DAFTAR PUSTAKA}

Agisimanto, D., C. Martasari, A. Supriyanto. 2007. Perbedaan primer RAPD dan ISSR dalam identifikasi hubungan kekerabatan genetik jeruk siam (Citrus suhuniensis L. Tan) Indonesia. J. Hort. 17(2):101-110.

[BPS] Badan Pusat Statistik. 2018. Konsumsi rata- rata per kapita seminggu beberapa macam bahan makanan penting, 20072014. https://www.bps.go.id/linkTabel Statis/ view/id/950. [11 Januari 2017].

[BRC] Biofarmaka Research Center. 2015. Bawang merah (Allium cepa). http:// biofarmaka.ipb.ac.id/biofarmaka/2015/ Artikel\%20Nanotech\%20Herbal\%20-\% 20Bawang\%20Merah.pdf. [20 Januari 2017].

[Ditbenih Hortikultura] Direktorat Perbenihan Hortikultura. 2018. Database varietas terdaftar hortikultura. http://varitas.net/ dbvarietas/cari.php?type $=$ jenis $\& q=$ baw ang + merah $\&$ Submit $=\mathrm{S}+\mathrm{E}+\mathrm{A}+\mathrm{R}+\mathrm{C}+\mathrm{H}$. [5 Februari 2018].

Husain, I., A. Purwito, A. Husni, K.H. Mutaqin, S. Susanto. 2011. Evaluasi keragaman genetik mutan harapan generasi MV1 jeruk keprok SoE (Citrus reticulata Blanco) berdasarkan penanda morfologi dan ISSR. J. Hort. Indonesia. 7(2):102110.

Kaeni, E., Toekidjo, S. Subandiyah. 2014. Efektivitas suhu dan lama perendaman bibit empat kultivar bawang merah (Allium cepa L. kelompok Aggregatum) pada pertumbuhan dan daya tanggapnya terhadap penyakit moler. Vegetalika. 3(1):53-65.

Mukherjee, A., B. Sikdar, B. Ghosh, A. Banerjee. 2013. RAPD and ISSR analysis of some economically important spesies, varieties, and cultivars of genus Allium (Alliaceae). Turkish Journal Botany. 37:605-618.

Naktuinbow. 2010. Calibration book onion and shallot. https://www.naktuinbouw.nl/ sites/default/files/Onion $\% 20 \% 26 \% 20$ sh allot\%20calibration\%20book.pdf. [15 September 2016].

[PPVT] Pusat Perlindungan Varietas Tanaman dan Perizinan Pertanian. 2013. Panduan Pelaksanaan Uji, Kebaruan, Keunikan, Keseragaman, dan Kestabilan Bawang Merah. Jakarta (ID): Kementrian Pertanian Republik Indonesia.

Prakoso, E.B., S. Wiyatiningsih, H. Nirwanto. 2016. Uji ketahanan berbagai kultivar bawang merah (Allium ascalonicum) terhadap infeksi penyakit moler (Fusarium oxysporum f.sp. cepae). Plumula. 5(1):10-20.

Samiei, L., M. Kiani, H. Zarghami, F. Memariani, M.R. Joharchi. 2015. Genetic diversity and interspecific relationships of some Allium L. spesies using inter simple sequence repeat markers. Bangladesh J. Plant Taxon. 22(2):67-75.

Sari, V., Miftahudin, Sobir. 2017. Keragaman genetik bawang merah (Allium cepa $\mathrm{L}$.) berdasarkan marka morfologi dan ISSR. J. Agron. Indonesia. 45(2):176-182. 
Sobir, M. Syukur. Genetika Tanaman. Bogor (ID): IPB Press.

Supriyadi, A., S.I. Rochdjatum, S. Djauhari. 2013. Kajian penyakit pada tanaman bawang merah yang dibudidayakan secara vertikultur di Sidoarjo. J. HPT. 1(3):27-40.

Syukur, M., S. Sujiprihati, R. Yunianti. 2015. Teknik Pemuliaan Tanaman. Jakarta (ID): Penebar Swadaya.

Udiarto, B.K., W. Setiawan, E. Suryaningsih. 2005. Pengendalian Hama dan Penyakit pada Tanaman Bawang Merah dan Pengendaliannya. Bandung (ID): Balai Penelitian Tanaman Sayuran.
Wahdah, R., B.F. Langai, T. Sitaresmi. 2012. Keragaman karakter varietas lokal padi pasang surut Kalimantan Selatan. Penelitian Pertanian Tanaman Pangan. 31(3):158-165.

Wiyatiningsih, S., B. Hadisutrisno, N. Pusposenjojo, Suhardi. 2009. Masa inkubasi dan intensitas penyakit moler pada bawang merah di berbagai jenis tanah dan pola pergiliran tanaman. J. Pertanian Mapeta. 11(3):192-198.

Zietkiewicz, E., A. Rafalski, D. Labuda. 1994. Genome fingerprinting by simple sequence repeat (SSR) - anchored polymerase chain reaction amplification. Genomics. 20:176-183. 